\title{
Epstein-Barr Virus Positive
}

National Cancer Institute

\section{Source}

National Cancer Institute. Epstein-Barr Virus Positive. NCI Thesaurus. Code C129454.

Indicates that Epstein-Barr virus has been detected in a sample. 